\title{
Returning to Lady Lumley's Schoolroom: Euripides, Isocrates, and the Paradox of Women's Learning
}

JAIME GOODRICH

Wayne State University

Dans la mesure où la fin première de l'éducation humaniste était de préparer les jeunes hommes à une carrière publique, les spécialistes de la Renaissance se sont tout naturellement intéressés aux quelques femmes qui, issues de l'élite, avaient pu étudier le latin et le grec: leur éducation a ainsi été présentée, tantôt comme un pur ornement intellectuel, tantôt comme l'instrument d'un exercice indirect du pouvoir. À travers le cas des traductions des classiques de l'Antiquité composées par Jane, Lady Lumley, cet article examine les réactions d'une femme lettrée à l'égard des principes politiques sous-jacents au programme d'éducation humaniste. Principalement connue pour sa traduction de l'Iphigénie en Aulide d'Euripide, Lumley a aussi traduit en latin cinq discours d'Isocrate. Alors que la critique a jusqu'à présent relégué son Iphigénie au simple rang d'exercice d'école, cet article prend l'éducation de Lumley au sérieux, en relisant son Iphigénie à la lumière de ses traductions d'Isocrate, auteur dont les cuvres était régulièrement inscrites aux programmes de lecture humanistes. L'examen des traductions composées par Lumley, avec les dédicaces qui les accompagnent, révèle ici l'intérêt soutenu de cette dernière, non seulement pour les théories politiques contemporaines ("commonwealth theory»), mais aussi, comme le montre finalement son Iphigénie, pour leurs conséquences à l'égard des femmes.

“W the humanist education of early modern women resulted in a cultural paradox. ${ }^{1}$ While humanist educators claimed that training in Latin and Greek would prepare young men for government service, women were traditionally denied public careers. As a result, Anthony Grafton and Lisa Jardine concluded that women's learning was purely decorative: "Within the humanist confraternity (sic) the accomplishment of the educated woman (the 'learned lady') is an end 
in itself, like fine needlepoint or the ability to perform ably on lute or virginals." More recently, scholars have implicitly offered another response to this question by demonstrating that Englishwomen composed translations that transformed their knowledge of foreign languages into a source of political agency with public applications. ${ }^{3}$ This critical shift is evident in scholarly responses to Jane, Lady Lumley, the first to translate a Greek play into English. While classical scholars portrayed Lumley's freehanded reworking of Euripides's Iphigenia at Aulis as a schoolroom exercise with little literary merit, feminist critics have rehabilitated this text as a political commentary on the execution of Lady Jane Grey. ${ }^{4}$ Indeed, scholars have recently distanced Lumley's Euripides from her schoolroom productions, epitomized by her presumably more literal Latin versions of six Greek orations by Isocrates. ${ }^{5}$

Yet Lumley's translations of Isocrates offer crucial insight into the ways that learned women dealt with the cultural paradoxes inherent in their educations. Isocrates's orations were a staple of male education in the early modern period, used to teach rhetoric and political theory. Well-known humanists such as Rudolf Agricola, Desiderius Erasmus, and Juan Luis Vives translated Isocrates into Latin, placing Lumley within mainstream humanist translation practices. ${ }^{6}$ Scholars may have neglected Lumley's Latin compositions, since translating Isocrates into Latin was a fairly standard exercise in humanist pedagogy. Nevertheless, Lumley's versions of Isocrates are the only extant translation of the Greek orator by a sixteenth-century Englishwoman, presenting a new question about learned women: "Humanist education-with what effect?" That is, how did the political underpinnings of the humanist curriculum, as represented by Isocrates's orations, shape the way that Lumley thought and translated? As Diane Purkiss has argued in relation to Lumley and Elizabeth Cary, "[r] eceiving a male education means absorbing male values. In effect, it means learning to think like a man."7 This essay will consider to what extent Lumley "absorb[ed]" commonwealth theory-an important component of male schooling-by situating Lumley's Tragedie of Euripides Called Iphigeneia within its material and literary contexts. Five translations of Isocrates (ca. 1550s) and two dedicatory epistles to her father (Henry Fitzalan, Earl of Arundel) precede her version of Euripides in BL Royal MS 15 A ix: a fragment of Ad Demonicum (Oration 1; fol. 2-2v), and complete drafts of Ad Nicoclem de regno (Oration 2; fol. 5-11), Symmachica (Oration 3; fol. 12-22), Evagoras (Oration 4; fol. 24-39v), and Oratio de pace (Oration 8; fol. 41-62v). ${ }^{8}$ Taken 
together, the translations in this manuscript function as an extended meditation on governance that subtly advances contemporary political principles. Lumley translates her sources in ways that emphasize their political applications, showing an interest in commonwealth theory and, eventually in her Iphigeneia, its ramifications for aristocratic women.

One of the key arguments that sixteenth-century educators made on behalf of humanist training was its political usefulness, particularly in terms of benefiting the English commonwealth. As recent scholarship has pointed out, "commonwealth" had two primary meanings: "In a weak sense, it could be used to describe any polity; in a strong sense, it was used to discuss what form of polity was most conducive to the common good."' Political treatises of this period often invoked this second sense, depicting the ideal commonwealth as a collective entity in which the prince as well as commoners contributed to the larger welfare of the state. As the Doctor in Thomas Smith's Discourse of the Commonweal of This Realm of England (ca. 1549) remarks, "we be not born only to ourselves but partly to the use of our country, of our parents, of our kinfolk, and partly of our friends and neighbors." ${ }^{10}$ If the ideal commonwealth was defined by this sense of shared enterprise, it required a ruling class who would advance the good of the entire commonwealth rather than their personal interests. In Thomas Starkey's Dialogue between Pole and Lupset (ca. 1529-32), "Pole" states, "they wych have authoryte \& rule of the state loke not to theyr owne syngular profyt nor to the pryvate wele of any one parte more then to the other, but refer al theyr consyle actys \& dedys, to the commyn wele of the hole...." ${ }^{11}$ Proponents of humanist education argued that classical literature could impart these political tenets. Smith, for example, claimed that moral philosophy had direct applications to governance: "What part of the Commonweal is neglected by moral philosophy? Does it not teach first how every man should guide himself honestly? Secondly, how he should guide his family wisely and prophetically, and thirdly it shows how a city or a realm or any other Commonweal should be well ordered and governed." ${ }^{12}$ Once a student learned to live according to a moral code derived from classical wisdom, he would be ready to establish order within the microsystem of the domestic sphere as well as the macrosystem of the polity.

As authors known for their moral and political wisdom, Euripides and Isocrates were both central to later stages of the humanist curriculum. Isocrates 
may have been the Greek writer most commonly taught in Tudor grammar schools, but he also appeared in the curricula of elite male students, including Edward VI, as well as the universities. ${ }^{13}$ The catalogue of the Lumley library reveals that Lumley had the opportunity to keep abreast of contemporary enthusiasm for Isocrates even if she did not attend grammar school or university. ${ }^{14}$ Besides containing a complete Greek edition of Isocrates's works (no. 1991), Arundel's library possessed Latin translations by Agricola (Disticha catonis, 1520 and 1526; nos. 2068 and 2082), Johann Lonicer (Isocratis ... orationes, 1529; no. 1889), Vives (Omnia opera, 1555; no. 2018) and Hieronymus Wolf (Isocratis orationes omnes, 1549; no. 1894). When Arundel acquired Thomas Cranmer's library in 1553, he received further Latin versions of Isocrates by Erasmus (Institutio principis christiani, 1519; no. 1740) and anonymous translators (BL Royal MS 10 B ix; no. 1189). Lumley may also have read Thomas Elyot's The Boke Named the Governour (no. 2262), which recommends that students memorize Isocrates's first and second orations:

Isocrates, concerning the lesson of oratours, is everywhere wonderful profitable, havinge almost as many wyse sentences as he hath wordes, and with that is so swete \& delectable to rede ... and in persuadynge as well a prynce as a pryvate person to vertue, the two very lyttell and compendious warkes, wherof he made the one to kyng Nicocles, the other to his frende Demonicus, wolde be perfectly kanned and had in continuall memorye. ${ }^{15}$

Lumley was therefore probably aware that humanists in England and elsewhere valued Isocrates because of his political relevance and rhetorical skill.

Euripides may have been taught less frequently than Isocrates, yet the dramatist also had a place in the university curriculum. Somewhat hyperbolically, Ascham wrote to former fellow student Richard Brandisby in 1542 that "Sophocles and Euripides are now better known here [at Cambridge] than Plautus was when you were here." ${ }^{16}$ Perhaps Lumley gained her enthusiasm for Euripides from her husband (John, Baron Lumley) or brother (Henry Fitzalan, Baron Maltravers), who both enrolled in Queens' College, Cambridge in 1549. Yet the Lumley catalogue suggests that Lumley's interests should be situated within a broader humanist context, especially as her translation was based on Erasmus's Latin version of Iphigenia at Aulis (1506), which entered Arundel's library in 1553 as part of Cranmer's collection (nos. 1591, 1736). Erasmus's 
translations of Hecuba and Iphigenia initiated a surge of Euripidean imitations and adaptations across Europe. ${ }^{17}$ Furthermore, in De ratione studii (1521; no. 1759a), Erasmus ranked Euripides as the third most important Greek poet after Aristophanes and Homer in terms of style and content. ${ }^{18}$ While Elyot does not specifically mention Euripides in the Governour, he does note the moral value of drama: "whan a man is comen to rype yeres, and that reason in hym is confyrmed with serious lernyng and long experience: than shall he, in redyng tragedies execrate and abhorre the intolerable life of tirantes...." ${ }^{19}$ Lumley probably knew, then, that Euripides and other classical dramatists were highly regarded for their moral qualities. Erasmus's utilitarian attitude toward Greek drama may even have influenced Lumley's free treatment of her Greek sources. In the preface to his Iphigenia, Erasmus notes that he translated the play "a little more freely and also a little more expansively" than Hecuba, stating that he would use even more license in the future: "I should not be reluctant to alter the style and topics of the choruses; and I should prefer either to treat of some commonplace or to deviate into some agreeable digression.... For it seems to me that nowhere did the ancients write more foolishly...." ${ }^{20}$ As demonstrated below, Lumley similarly removes material without direct moral or political applications from her source texts.

Nevertheless, the Arundel library's holdings on female education offered little precedent for women to translate Greek literature. In De institutione foeminae (1555; no. 2018), Vives draws a stark contrast between the goals of educating men and women:

though the preceptes for men be innumerable: women yet may be enfourmed with few wordes. For men must be occupied both at home and forth a brode, both in theyr own matters and for the common weale. ... As for a woman hath no charge to se[e] to, but her honestie and chastyte. Wherfore whan she is enfurmed of that, she is sufficiently appoynted. ${ }^{21}$

Vives consequently recommended that women read the Bible and Church Fathers, offering no encouragement for women to learn Greek. ${ }^{22}$ The Arundel library also contained two copies of the program that Vives drew up for Mary Tudor (De ratione puerilis; nos. 1924a and 2018), which had a more political orientation appropriate to Mary's role as putative heir to the throne. ${ }^{23}$ While Vives does not suggest that Mary study Greek, he does recommend that she 
read secular Latin works with political applications, including Plutarch in Latin, Cato's Distichs, and "some dialogues of Plato-especially those which concern the government of the state." ${ }^{24}$ If Mary followed this plan, she may have encountered Agricola's Latin translation of Isocrates, depending on the edition of the Distichs used. Some early modern Englishwomen did learn Greek, but if they began with Isocrates, little evidence remains to show it. Mary Roper Basset, Mildred Cooke Cecil, and Margaret Gigs Clement concentrated on translating patristic texts. While Jane Grey read Plato, she alluded to Eusebius when she hoped to demonstrate her learned credentials to Heinrich Bullinger. ${ }^{25}$ Lumley's translations are closest in spirit to the schooling of Elizabeth Tudor, who was reading Isocrates in Greek by $1550 .{ }^{26}$ Elizabeth produced Latin versions of Isocrates's second and third orations before 1557 (both now lost), and she supposedly translated one of Euripides's plays into Latin (also lost). ${ }^{27}$ Scholars have argued that Arundel educated his daughters as potential brides for Edward VI, which may explain the unusually political orientation of Lumley's curriculum. ${ }^{28}$ No matter the impetus for her training, Lumley had a rare familiarity with the Greek literature standard in advanced humanist curricula.

Lumley's translations of Isocrates show that she recognized and valued the moral, political, and stylistic applications of his orations, much as any male student would. Lumley offers her translations of the second and third orations to her father as a New Year's gift: "ego impulsa eram, ut duas has breves orationes quas e graecis in latina converti, quasi specimen aliquod studii mei tibi dono offerrem..." (I was moved to offer these two short orations, which I turned from Greek into Latin, to you as a gift, as some sign of my study). ${ }^{29}$ Yet if Lumley initially characterizes these translations as the fruits of her schooling, she also claims that these works held political wisdom that might benefit her father:

eas autoritati tuae et prudentiae aptissimas esse judicavi. Priorem enim Isocrates orator eloquentissimus scripsit ad Nicoclem rempublicam Cypri insulae administraturum, quo bonis institutis ac rectis vivendi praeceptis instructus, aptior efficeretur ad eam gubernandam. In hac regis atque magistratus officium, et quo modo in quavis re se gerere debet erga subditos, sapientissime, brevissimeque docet. In altera vero Isocrates 
Nicoclem loquentem ad subditos facit, in qua ... populi observantiam erga magistratus ingeniossime declarat....

(I judged them most fitting for your authority and wisdom. For the most eloquent orator Isocrates wrote the first to Nicocles, who would govern the commonwealth of the island Cyprus, so that instructed by good customs and right precepts of living, he would be made more apt for ruling it. In this [oration] he teaches most wisely and briefly the office of the king and the magistrate, and in what manner he ought to conduct himself in any matter at all toward subjects. Yet in the other [oration], Isocrates causes Nicocles to speak to his subjects, in which ... he declares most ingeniously the people's reverence toward magistrates; fol. $4-4 \mathrm{v}$ )

These orations may have been standard reading material in the humanist schoolroom, but Lumley gestures at the political agendas of that curriculum by referring to the "commonwealth" as well as to Arundel's "authority." In the preface to her version of the fourth oration, Lumley praises Isocrates's exemplary style and moral precepts: "Ex huius lectione incredibilem semper cepi voluptatem. Nam in verborum splendore est elegans, compositione aptus, facultate copiosus, sententiis sapiens, et genere toto gravis" (From this reading, I have always taken incredible pleasure. For it is elegant in the splendour of its words, apt in composition, plentiful in ability, wise in moral sentences, and weighty in every way; fol. 23). Lumley's presentation of Isocrates as a source of elegant "moral sentences" reflects contemporary perceptions of his pedagogical value, demonstrating her awareness of humanist assessments of Isocrates.

Yet this praise of Isocrates's political and moral wisdom was not merely conventional, as Lumley carefully reshaped the orations to emphasize these elements. Like many translators of this period, Lumley claims to translate Isocrates faithfully, remarking of her versions of orations 2 and 3: "Quae quidem ita a me transferuntur, ut et graeca latinis, atque latina graecis facile respondeant" (Indeed these [orations] are translated thus by me so that both the Greek may easily answer to the Latin and the Latin to the Greek; fol. $4 \mathrm{v}$ ). We might consequently expect her translations to be highly literal, but Lumley alters Isocrates's orations in ways that anticipate her treatment of Euripides. Some of these changes result from occasional difficulties with Greek, as when Lumley mistranslates Isocrates's observation in the fourth oration: "Kūpos 


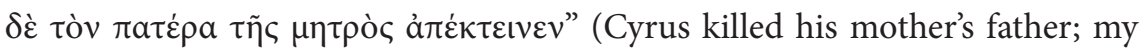
translation) becomes "Cyrus patrem et matrem interfecit" (Cyrus killed his father and mother; Lumley, fol. 30v). ${ }^{30}$ Such sloppiness suggests that Lumley's attention or grasp of Greek faltered at times, perhaps explaining why she used Erasmus as a crib when she turned to Euripides, a more difficult author. Other alterations coincide with Lumley's dedicatory praise of Isocrates, particularly her excision of material present in sixteenth-century Greek editions but lacking moral or political relevance. Lumley's version of oration 2 omits sections $2.40-54$, passages dealing with literature that might have seemed unrelated to Isocrates's advice on governance. Lumley takes even greater liberties with oration 8 , which advises the Athenians to pursue peace rather than war, removing 8.72-73 (on the difference between admonishing and denouncing), 8.80 (on Isocrates's concern for his reputation), and 8.121-44 (on Athenian political history). In order to smooth over this last omission, Lumley inserts a transitional sentence emphasizing the golden rule: "Quae cum ita sint, vestrum est virtutem amplecti, diligere, atque admirari, talesque vos ipsos erga alios prebere, quales illos adversus vos esse velitis" (Since things are thus, it is yours to embrace, cherish, and admire virtue, and to behave yourself toward others as you would wish others to behave toward you; Lumley, fol. 62v). Such changes rework oration 8 so that it focuses more on governance and morality than Athenian politics.

Lumley also makes the orations more pertinent to Tudor politics by consistently translating Isocrates into the language of commonwealth theory. For example, she modifies Isocrates's explanation of his goals in oration 2: "si explicare potuissem, quae faceres, aut a quibus abstineres, quo respublica tua recte administrari possit" (if I could declare what you should do, or from what you should refrain, how your commonwealth could be governed correctly; Lumley, fol. 5). Lumley collapses Isocrates's doublet "state and kingdom" ( $\tau \grave{\eta} v$

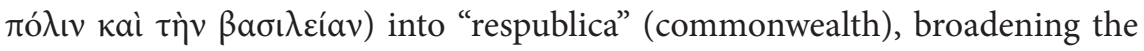
work's applications beyond the context of ancient Greece. ${ }^{31}$ Lumley also generalizes Isocrates's orations by removing specific financial, military, and political details. In oration 3, Isocrates argues that military affairs are handled better in monarchies than in other forms of government because kings more easily prevail "in raising troops, and handling them so as to mislead and forestall the enemy, and in winning people over, now by persuasion, now by force, now by bribery, now by other means of conciliation" (Norlin, Isocrates I, p. 89). Lumley shortens this list so that it discusses warfare more generally: "non solum copias 
facile parando, atque eisdem recte utendo, verum etiam aliis suadendo, alios cogendo: adeo ut nihil desiderari possit" (not only by easily providing troops, and by using them correctly, but also by persuading some, by forcing others: so much that nothing could be desired; Lumley, fol. 15v). These changes suggest that Lumley valued Isocrates for his potential relevance to commonwealth theory and good governance.

If Lumley's preface to her translations of the second and third orations emphasizes Isocrates's political guidance, she consistently translates Isocrates in ways that suggest leaders must put the common good before their personal welfare. In oration 4, Isocrates commends Evagoras's decision to return from exile and defend his hereditary right to rule Cyprus: "this he took as his guiding principle, which those who would be god-fearing men must take-to act only in self-defence and never to be the aggressor; and he chose either by success to regain the throne or, failing that, to die." ${ }^{32}$ Lumley, however, transforms Evagoras into a model of patriotic sentiment who protects Cyprus even while endangering his own life by adding the phrase "tuendi patriam [defending the fatherland]": "Nactus hanc occasionem tuendi patriam, quae probis viris negligenda non est; et ne alii eum anteverterent cupiebat, vel faeliciter bellum gerens regnare, vel in adversam incidens fortunam mori" (Having obtained this occasion of defending the fatherland, which must not be neglected by upright men, and lest others overtook him, he desired either, happily waging war, to rule or, falling into adverse fortune, to die; Lumley, fol. 28v). Similarly, in the second oration Lumley underscores Isocrates's contention that kings must be as brave as their subjects:

Indecorum esse puta, privatos mortem voluntariam subire, ut mortui gloriam adipiscantur, et reges ea instituta non tenere, ex quibus vivi laudem assequantur. Expete virtutis potius, quam corporis monumenta relinquere: ut tu, atque etiam cives tutam quietamque vitam agatis. $\mathrm{Si}$ pericula subire coactus fueris, elige potius mortem praeclaram, quam vitam turpem aut inhonestam.

(Think it shameful, that private men undergo a voluntary death in order to attain glory in death, and kings do not have these customs, by which they strive for praise while alive. Desire to leave monuments of virtue, rather than of your body: so that you, and also the citizens, may lead a safe and 
quiet life. If you are forced to undergo dangers, choose an excellent death rather than a base or dishonourable life; Lumley, fol. 10-10v)

Besides stressing the idea that virtue leads to prosperity by rendering "ả $\varphi \varphi \alpha ́ \lambda \varepsilon ı \alpha v "$ (security; Norlin, Isocrates I, pp. 60-61) with the doublet "tutam quietamque vitam" (safe and quiet life), Lumley emphasizes that kings should

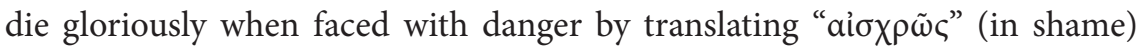
with the doublet "turpem aut inhonestem" (base or dishonourable). Lumley thus presents rulers as stewards of the common good, who serve their countries rather than their own interests.

Just as commonwealth theory held that the household was a microcosm of the country, Lumley heightens Isocrates's portrayal of personal morality and domestic order as the foundations of political success. For instance, Lumley reworks Isocrates's explanation of why the Spartans lost their empire in the eighth oration in order to suggest that rulers must demonstrate unimpeachable morality: "Hunc enim dominatum obtinuerunt propter modestiam tollerantiamque, quibus in reipublicae administratione usi sunt, quo rursus propter avaritiam luxuriamque, quibus postea delibuti contaminatique erant, brevi post privabantur.... arbitrati omnia sibi licere, maximos tumultus summasque seditiones excitabant" (For they obtained this mastery because of the modesty and tolerance that they used in governing the commonwealth, of which on the contrary they were deprived shortly after because of the avarice and luxury by which they were afterwards besmeared and contaminated. ...having judged that all things were permitted to them, they roused the greatest tumults and highest seditions; Lumley, fol. 59v). Lumley dwells upon the immorality of the Spartans in order to emphasize the connection between their personal decadence and political

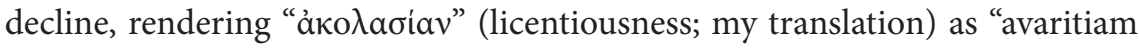

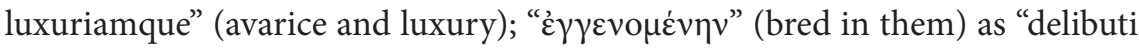

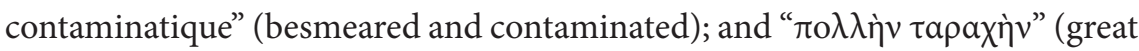
confusion) as "maximos tumultus summasque seditiones" (greatest tumults and highest seditions). ${ }^{33}$ This contention implicitly draws on commonwealth theory, which Lumley explicitly evokes by rendering "aủ $\tau \tilde{\eta} \mu \varepsilon \lambda \varepsilon \tau \omega \mu \varepsilon \dot{v} v \eta$ " (taking care of it [i.e., their dominion]; my translation) as "reipublicae administratione" (governing the commonwealth). Lumley also emphasizes the need for monarchs to exercise self-control, altering a passage in the third oration that counsels kings to maintain domestic harmony by avoiding extramarital 
affairs: "Decet eos qui regale imperium recte administrant, non solum civitates, verum etiam suas atque privatas aedes mutuo amore et benevolentia sibi arctissime devincire" (It befits those who govern a royal dominion rightly, to bind most closely to themselves with mutual love and benevolence not only their states, but also their own private houses; Lumley, fol. 18v). Lumley stresses

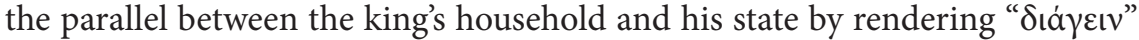
(to preserve; Norlin, Isocrates I, pp. 100-01) as "sibi arctissime devincire" (to bind most closely to themselves) and "ónovoía" (harmony) as "mutuo amore et benevolentia" (mutual love and benevolence). Significantly, this mention of reciprocity implies that the members of the royal household, including women, could play a part in establishing a "mutual love and benevolence" that might benefit the commonwealth, an idea that, as demonstrated below, Lumley would later pursue in her translation of Euripides.

Finally, Lumley's translations of Isocrates depict learning as the basis of personal virtue and, by extension, proper governance. In oration 4, Isocrates commends Evagoras's paternal care, obliquely praising his son Nicocles: "In addition to these blessings, that which seems to be the rarest and most difficult thing to win - to be blessed with many children who are at the same time good-not even this was denied to him, but this also fell to his lot" (Van Hook, p. 45). Lumley's version, however, omits Evagoras's role as a father in order to focus on his learning: "Ad haec quod rarum esse jud[ic]etur ac perdifficile, et ad discendum facilis exstitit, atque incredibilem etiam brevi cognitionem assecutus est" (To these things, that which may be judged rare and most difficult: he both appeared easy to be taught, and also he shortly obtained an incredible knowledge; Lumley, fol. 37v). Perhaps Lumley altered this passage because it served as a painful reminder of her family's own lack of progeny. ${ }^{34}$ Yet this focus on Evagoras's mind also anticipates Lumley's later reworking of Isocrates's final exhortations to Nicocles: "Nec decet te animo magno aut elato esse, si istis praeceptis institutus, melior aut praestantior extiteris, sed dolere potius ... si non longe praestiteris aliis omnibus qui in huiusmodi honoris gradu collacati fuerint. Te ipsum omnibus his erroribus studio atque diligentia facile liberare potes" (It is not fitting for you to have a great or elevated heart, if trained by these precepts, you appear better or more excellent, but rather grieve ... if you do not excel by far all others who have been placed in the degree of this kind of honour. You can easily free yourself from all these errors with study and diligence; Lumley, fol. 39). Lumley adds two references to Nicocles's learning: 
"istis praeceptis institutus" (trained by these precepts) and "studio atque diligentia facile" (easily with study and diligence). She also emphasizes the benefits

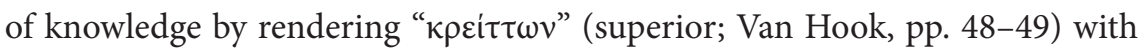
the doublet "melior aut praestantior" (better or more excellent). Additionally, Lumley suggests that education will prepare Nicocles to avoid moral failings

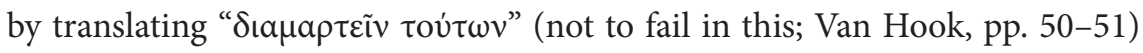
as "liberare omnibus his erroribus" (to free yourself from all these errors). Isocrates thus seems to support the humanist contention that learning inculcates morality and so could mould an ideal prince.

Lumley's versions of Isocrates's orations offer an important, if often overlooked, context for her translation of Euripides, particularly her amplification of the play's political nuances. Scholars have already noted that Lumley incorporates references to political theory in her translation, arguing that she drew upon her husband's English version of Erasmus's Institutio principis christiani (1550; BL Royal MS 17 A xlix). ${ }^{35}$ Yet Lumley's translations of Isocrates suggest her solid grounding in the classical tradition that informed Erasmus's views of governance. Indeed, Erasmus appended his translation of Isocrates's second oration to the Institutio as if to signal the classical origins of his treatise. Lumley's interest in the political applications of Isocrates's orations may help explain her decision to translate Iphigenia rather than Hecuba. While the latter play focuses on Hecuba's grief over her son's death, in the former Agamemnon is torn between family and politics when Artemis demands the sacrifice of his daughter Iphigenia in exchange for allowing the Greek fleet to depart for Troy and retrieve his sister-in-law Helen. Erasmus's translation of Iphigenia only emphasizes the play's political applications. In the Greek play, Achilles reports that his countrymen accuse him of being enslaved by love when he attempts to dissuade them from sacrificing Iphigenia: "First were these to turn against me, ... / Taunted me as thrall to marriage." ${ }^{36}$ Erasmus's version frames these criticisms in political terms: "Meque dicebant amore vincier connubii, / Proin parum consulere Graium copiarum commodis, / Quippe privatis adactum ac servientem affectibus" (And they said that I was conquered by love of matrimony, / Therefore I have too little regard for the Greek army's commodity, / For I am subjected to and serving personal desires). ${ }^{37}$ Lumley in turn maintains Erasmus's depiction of the clash between Achilles's private interests and public role: "they also did speke againste me saienge, that I was in love withe her and 
therfore I did preferre myne owne pleasure, above the commodite of my countrie" (Lumley, fol. 90v). Significantly, Lumley streamlines the play in order to concentrate on its political elements; besides following Erasmus's suggestion of eliminating the choruses, she omits mythical references and most of the subplot involving Achilles. ${ }^{38}$ The play consequently becomes a case study of how a ruler and his family handle a moral and political dilemma, complementing the translations of Isocrates presented to her father.

In reshaping the play, Lumley heightens the tensions that arise when Agamemnon can only advance his political interests by destroying his family. As captain of the Greek army, Agamemnon is bound to assist the fleet's departure for Troy, a duty underscored by Lumley's reworking of Achilles's entrance. In the source texts, Achilles voices his own frustration with the delay, but Lumley transforms Achilles into a spokesman for the troops: "I beinge moved withe the pitious complaintes of the people, am compelled to enquire of their captaines the cause, whi they beinge constrayned to forsake both their wives, their children, and also their countrie, nowe lie heare idlely without any valiant dedes doinge" (Lumley, fol. 81v, emphasis added to show interpolation). By referring to the "pitious complaintes of the people," Lumley pointedly evokes Agamemnon's role as a leader who must consider the welfare of his subjects. Yet as the play has already established, Agamemnon has an obligation to preserve his family. In both of Lumley's sources, Agammemon sorrowfully imagines his daughter's curses when she learns that she will die instead of marrying Achilles: "O me the pity of it! I hear her pray_ / 'Ah, father, wilt thou slay me! Now such bridal / Mayst thou too find, and all who thou dost love"' (Way, 1l. 462-64). ${ }^{39}$ Lumley reworks this passage so that Agamemnon envisions Iphigenia lamenting her lack of recourse:

I have pitie of the litell gerle, for I knowe she will speake thus unto me, O father will you kill me? if you forsake me, of whom shall I aske remedie, Alas what answer shall I make to this, suerly nature oughte to move me to pitie, and if that wolde not, yet shame shulde let me. Alas, Alas: What a greate reproche is it, the father to be an occasion of his owne childes deathe. Howe therfore am I trobled? On this parte pitie and shame, on the other side honor and glorie dothe moche move me. (Lumley, fol. 76-76v, emphasis added to show interpolation) 
Lumley's expansion emphasizes that Agamemnon is caught in a bind between paternal "pitie and shame" and military "honor and glorie," pinpointing the conflict he faces when domestic and national interests clash.

If Lumley's Isocrates implied that members of royal households could contribute to the public good, her translation of Euripides presents Clytemnestra as a potential political counsellor with a solid grasp of commonwealth theory. In Lumley's sources, Clytemnestra attempts to dissuade her husband by reminding him of his patriarchal role: "is it thine / Only to flaunt a scepter, lead a host" (Way, 11. 1194-95). ${ }^{40}$ Lumley's Clytemnestra, however, contends that Agamemnon's paternal responsibility does not conflict with his military leadership: "you shall purchase your selfe the name of a cruell tyrante. For you weare chosen the captaine over the grecians to execute justice to all men, and not to do bothe me and also your children suche an injurie" (Lumley, fol. 88v, emphasis added to show interpolation). By suggesting that this breach of paternal obligations will undermine Agamemnon's responsibility "to execute justice to all men" - including his own family — and so transform him into a "cruell tyrante," Clytemnestra voices the familiar sentiment that a king's domestic and political obligations ought to align with one another. Drawing on this assumed parallel between domestic and political interests, the play even presents Clytemnestra as a counsellor. Clytemnestra claims that she cannot influence her husband: "I alone beinge a woman cannot perswade Agamemnon" (Lumley, fol. 84v). In Lumley's sources, however, Clytemnestra refers to her inability to persuade the fleet: "I am come-a woman, as thou dost behold- / Unto this array of seafolk, lawless" (Way, 11. 913-14). ${ }^{41}$ Yet if Lumley's Clytemnestra submits to the patriarchal authority of her husband, the Chorus-described by Lumley as "a companie of Women" (fol. 65v)—nonetheless advises Agamemnon, "folowe your wives councell: for it is not lawfull that a father shulde destroy his childe" (Lumley, fol. 88v). By substituting "folowe ... councell" for the source texts' "heed" (pareto, Erasmus, 1. 1711; $\pi \bullet \theta o v$, Way, 1. 1209), Lumley suggests that women may function as counsellors within the politicized sphere of the royal household. This idea is further supported by Clytemnestra's endorsement of the principle that the domestic sphere is a microcosm of the political sphere.

Indeed, Agamemnon's dilemma is resolved by the advice of another female counsellor, Iphigenia herself, who voluntarily surrenders her life on behalf of the expedition. Lumley makes several changes to Erasmus's Latin argument that suggest her approval of Iphigenia's decision: "Iphigenia her selfe chaunged 
hir minde, and perswadethe hir mother, that it is better for her to dye a glorious deathe, then that for the safegarde only of hir life, either so many noblemen shoulde fall out within themselves, or else suche a noble enterprise, beinge taken in hande, shulde shamefullye againe be let slippe" (Lumley, fol. 65). Lumley implicitly praises Iphigenia's ability to facilitate Greek military glory by translating "rem tantum" (such a matter; Erasmus, p. 271) as "suche a noble enterprise" and by adding the phrase "shamefullye againe." Within the play itself, Iphigenia advocates the political dictum that a state's demands should supersede the individual's concerns: "I wolde counsell you therfore to suffer this troble paciently, for I muste nedes die, and will suffer it willingelye. Consider I praie you mother, for what a lawfull cause I shalbe slaine. Dothe not bothe the destruction of Troie, and also the welthe of grece, whiche is the mooste frutefull countrie of the worlde, hange upon my deathe" (Lumley, fol. 91v-92). Once again, Lumley positions a royal woman as a potential counsellor by rendering the source texts' imperative "hear" (accipe, Erasmus, 1. 1955; äkovбov, Way, 1. 1374) as "counsell." Like Clytemnestra, Iphigenia appeals to the idea of justice, approximating Erasmus's "recta ratio" (right reason; Erasmus, 1. 1959) with "lawfull," in order to support commonwealth theory. By referring to "the welthe of grece" rather than "all ... Hellas" (Graeciae ... tellus tota, Erasmus, 1. 1960; "E $\lambda \lambda \alpha \varsigma$ i $\pi \tilde{a} \varsigma \alpha$, Way, 1. 1378), Iphigenia indicates that her personal interests must yield to the larger good. In doing so, Iphigenia implies that Agamemnon's duty as a king surpasses his obligations as a father, demonstrating patriotism congruent with the political ideals Lumley had already highlighted in Isocrates's orations.

Lumley also suggests that Iphigenia's intelligence permits her to resolve Agamemnon's dilemma. Scholars have already noted Lumley's emphasis on Iphigenia's mind, and this aspect of the translation may be indebted to Isocrates's portrayal of learning as a source of political wisdom. ${ }^{42}$ During an exchange about Agamemnon's disturbed mental state, Iphigenia appears to recognize that Agamemnon's roles as a father and leader may not be compatible:

AGAMEMNON: You knowe daughter, that he whiche rulethe an hooste shall have divers occations to be trobled.

IPHIGENIA: Althoughe in dede a captaine over an hooste shall be disquieted with sondrie causes, yet I praye you set aside all soche trobles, and be merie with us whiche are therfore come unto you. 
AGA. I will folowe your councell daughter, for I will rejoyse as longe as I may have your companie. (Lumley, fol. 78v-79, emphasis added to show interpolation)

Lumley causes Iphigenia to repeat Agamemnon's statement, hinting at a political awareness not evident in her sources. Additionally, Agamemnon responds by accepting Iphigenia's "councell" rather than stating that she has his complete attention, as in the source texts: "Yes, I am all thine now: my thoughts stray not" (Way, 1. 647). ${ }^{43}$ If these shifts subtly anticipate Iphigenia's later role as a counsellor, this conversation also highlights Iphigenia's intelligence when Agamemnon reacts mournfully to Iphigenia's apparent understanding of his predicament:

AGA. Trulye daughter the more wittely you speake, the more you troble me.

IPH. If it be so father, then will I studie to seme more folisshe that you may be delited.

AGA. Suerly I am constrained to praise gretlye your witte, for I do delite moche in it. (Lumley, fol. 79-79v)

While the Greek version of Agamemnon's last line states, "Ah me! This silence breaks my heart! I thank thee" (Way, 1. 651), Erasmus is more expansive: "Papae, silere non fero ipse nec queo, / Collaudo vero te proboque, filia" (Ah, I myself cannot bear to be silent nor am I able, / Truly I approve and praise you very much, daughter; 1l. 881-82). Lumley in turn interpolates a reference to Iphigenia's intellectual acumen so that Agamemnon praises her "witte." Additionally, Iphigenia's decision to go forward with the sacrifice becomes associated with her mind when Achilles marvels at her resoluteness: "Trulie I wonder gretelie at the bouldenes of your minde" (Lumley, fol. 93). In Lumley's sources, Achilles praises her "pectoris praesentia" (heart's courage;

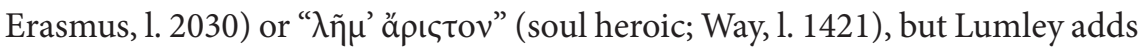
an intellectual component by mentioning "the bouldenes of [her] minde." As Isocrates had hoped for Nicocles, Iphigenia's intellect allows her to pursue the larger political good and so to benefit her people.

In the end, what effect did Lumley's humanist education have on the way that she thought and translated? Whether or not Lumley truly thought like 
a man, the translations found in BL Royal MS 15 A ix suggest that she was influenced by the political principles of commonwealth theory latent within humanist curricula. Lumley clearly viewed her classical source texts as repositories of moral and political guidance relevant to bureaucrats and aristocrats like her father. If humanists such as Erasmus and Elyot claimed that classical texts could teach young boys the fundamentals of public policy, Lumley highlights the political applications of her source texts. Lumley's thorough absorption of the tenets of commonwealth theory may account for moments within her Euripides that are troubling from a feminist perspective. Not only does Clytemnestra recognize her relative lack of power in relation to her husband's patriarchal role, but Iphigenia purposefully sacrifices herself for the larger political imperatives of her father, uncle, and people. It may be tempting to emphasize the larger mythological narrative in which Clytemnestra engineers her husband's murder in retribution for Iphigenia's death, but within Lumley's translation, Iphigenia nobly and praiseworthily dies for the greater good. Lumley's representation of these female characters may even offer a solution to the quandaries faced by learned women. While Clytemnestra and Iphigenia are circumscribed by patriarchy and confined to the private sphere, they nevertheless use their intellects to advance personal agendas and larger political goals. In portraying these characters as counsellors with knowledge of commonwealth theory, Lumley implies that aristocratic women could transform the domestic sphere into an arena for limited political action. This depiction of Agamemnon's family life seems germane to Lumley's position as the daughter and wife of men with established, and sometimes embattled, political careers. If Lumley's translations of Euripides and Isocrates remained safely out of the public sphere, she nevertheless could hope that they might offer political guidance to her father and possibly her husband. Ultimately, Lumley's schoolroom deserves serious consideration for what it can tell us about learned women's reactions to the political aspects of humanist pedagogy. Strongly influenced by commonwealth theory, Lumley's translations reveal the way that one woman attempted to reconcile the political imperatives of her humanist education with cultural restrictions on women's public roles. 


\section{Notes}

1. Lisa Jardine, "Isotta Nogarola: Women Humanists-Education for What?" History of Education 12 (1983), pp. 231-44. Also see Lisa Jardine, "Cultural Confusion and Shakespeare's Learned Heroines: 'These are old paradoxes,'” Shakespeare Quarterly 38.1 (1987), pp. 1-18; Hilda L. Smith, "Humanist Education and the Renaissance Concept of Woman," in Women and Literature in Britain 1500-1700, ed. Helen Wilcox (Cambridge: Cambridge University Press, 1996), pp. 9-29.

2. Anthony Grafton and Lisa Jardine, From Humanism to the Humanities: Education and the Liberal Arts in Fifteenth- and Sixteenth-Century Europe (London: Duckworth, 1986), p. 56.

3. See, for example, Micheline White, "Renaissance Englishwomen and Religious Translation: The Case of Anne Lock's Of the Markes of the Children of God (1590)," English Literary Renaissance 29.2 (1999), pp. 375-400, and Linda Shenk, Learned Queen: The Image of Elizabeth I in Politics and Poetry (New York: Palgrave Macmillan, 2010).

4. David H. Greene, "Lady Lumley and Greek Tragedy," The Classical Journal 36.9 (1941), pp. 537-47; Frank D. Crane, "Euripides, Erasmus, and Lady Lumley," The Classical Journal 39.4 (1944), pp. 223-28; Stephanie HodgsonWright, "Jane Lumley's Iphigenia at Aulis: multum in parvo, or, less is more," in Readings in Renaissance Women's Drama: Criticism, History, and Performance, ed. S. P. Cerasano and Marion Wynne-Davies (New York: Routledge, 1998), pp. 129-41; Danielle Clarke, The Politics of Early Modern Women's Writing (New York: Longman, 2001), pp. 83-88.

5. Marta Straznicky, Privacy, Playreading, and Women's Closet Drama 1550-1700 (Cambridge: Cambridge University Press, 2004), pp. 31-32; Deborah Uman, "'Wonderfullye astonied at the stoutenes of her minde': Translating Rhetoric and Education in Jane Lumley's The Tragedie of Iphigeneia," in Performing Pedagogy in Early Modern England: Gender, Instruction, and Performance, ed. Kathryn M. Moncrief and Kathryn R. McPherson (Farnham, UK: Ashgate, 2011), p. 58.

6. Agricola translated oration 1, Erasmus translated oration 2, and Vives translated orations 3 and 7.

7. Diane Purkiss, "Blood, Sacrifice, Marriage: Why Iphigeneia and Mariam Have to Die," Women's Writing 6.1 (1999), p. 40.

8. Marion Wynne-Davies argues that the Isocrates translations date from 1552 to 1557: "The Good Lady Lumley's Desire: Iphigeneia and the Nonsuch Banqueting 
House," in Heroines of the Golden Stage: Women and Drama in Spain and England 1500-1700, ed. Rina Walthaus and Marguérite Corporaal (Kassel: Edition Reichenberger, 2008), p. 118. Lumley's presentation copy of the fourth oration is extant in BL Royal MS 15 A ii, and she also translated Archidamus (oration 6): Royal MS 15 A i.

9. Early Modern Research Group, "Commonwealth: The Social, Cultural, and Conceptual Contexts of an Early Modern Keyword," The Historical Journal 54.3 (2011), p. 671.

10. Thomas Smith, A Discourse of the Commonweal of This Realm of England, ed. Mary Dewar (Charlottesville, VA: University Press of Virginia for the Folger Shakespeare Library, 1969), p. 16.

11. Thomas Starkey, A Dialogue between Pole and Lupset, ed. T. F. Mayer, Camden Fourth Series, vol. 37 (London: Offices of the Royal Historical Society, 1989), p. 36.

12. Smith, Discourse, p. 29.

13. T. W. Baldwin, William Shakespere's Small Latine \& Lesse Greeke (Urbana, IL: University of Illinois Press, 1944), vol. 1, pp. 22-24 and vol. 2, p. 649. Also see Gilbert Highet, The Classical Tradition: Greek and Roman Influences on Western Literature (Oxford: Oxford University Press, 1949), pp. 122-23.

14. The Lumley Library: The Catalogue of 1609, ed. Sears Jayne and Francis R. Johnson (London: British Museum, 1956). All references to entries in this catalogue will be provided parenthetically.

15. Thomas Elyot, The Boke Named the Governour (1537), fol. 34.

16. Roger Ascham, Letters of Roger Ascham, ed. Alvin Vos, trans. Maurice Hatch and Alvin Vos (New York: Peter Lang, 1989), p. 32.

17. Bruce R. Smith, Ancient Scripts and Modern Experience on the English Stage 1500-1700 (Princeton, NJ: Princeton University, 1988), p. 203.

18. Desiderius Erasmus, Collected Works of Erasmus, vol. 24, De ratione studii, trans. Brian McGregor (Toronto: University of Toronto Press, 1978), p. 669.

19. Elyot, fol. 33 .

20. Desiderius Erasmus, The Correspondence of Erasmus: Letters 142-297, 1501-1514, Collected Works of Erasmus, trans. R. A. B. Mynors and D. F. S. Thomson (Toronto: University of Toronto Press, 1975), vol. 2, p. 133, 135.

21. Juan Luis Vives, The Instruction of a Christen Woman, ed. Virginia Walcott Beauchamp, Elizabeth H. Hageman, and Margaret Mikesell, trans. Richard Hyrde (Urbana, IL: University of Illinois Press, 2002), p. 9.

22. Vives, p. 27. 
23. See Maria Dowling, Humanism in the Age of Henry VIII (London: Croom Helm, 1986), pp. 221-29; Aysha Pollnitz, "Christian Women or Sovereign Queens? The Schooling of Mary and Elizabeth," in Tudor Queenship: The Reigns of Mary and Elizabeth, ed. Alice Hunt and Anna Whitelock (New York: Palgrave Macmillan, 2010), pp. 127-42.

24. Vives and the Renascence Education of Women, ed. Foster Watson (New York: Longmans, Green \& Co., 1912), p. 147.

25. The Literary Remains of Lady Jane Grey, ed. Nicholas Harris Nicolas (London: Harding, Triphook, and Lepard, 1825), pp. 7-8.

26. Ascham, Letters, p, 167.

27. John Bale, Index Britanniae Scriptorum, ed. Reginald Lane Poole and Mary Bateson (1902; New York: AMS Press, 1989), fol. 157; Baldwin, vol. 1, p. 282.

28. Retha M. Warnicke, Women of the English Renaissance and Reformation (Westport, CT: Greenwood Press, 1983), p. 102.

29. BL Royal MS 15 A ix, fol. 4. Quotations of this work will be parenthetically cited hereafter; all translations from Latin throughout are mine.

30. Here I follow the phrasing of the two major sixteenth-century Greek versions: Isocrates, Isocrates nuper accurate recognitus et auctus (Venice, 1534), 16v; Isocratis Orationes, ed. Demetrios Chalkokondyles (Venice, 1535), 38v.

31. Isocrates I, trans. George Norlin (New York: G. P. Putnam's Sons, 1928), pp. 40-41. Quotations of this work will be parenthetically cited hereafter.

32. Isocrates III, trans. Larue Van Hook (Cambridge, MA: Harvard University Press, 1945), p. 19. Quotations of this work will be parenthetically cited hereafter.

33. Isocrates II, trans. George Norlin (London: William Heinemann, 1929), pp. 72-73.

34. Her brother died in 1556, her stepmother Mary and her sister Mary Howard, duchess of Norfolk both died in 1557, and Lumley herself was childless.

35. Elaine V. Beilin, Redeeming Eve: Women Writers of the English Renaissance (Princeton: Princeton University Press, 1987), pp. 155-57; Clarke, p. 84.

36. Euripides, Iphigenia at Aulis, Rhesus, Hecuba, The Daughters of Troy, Helen, ed. and trans. Arthur S. Way (Cambridge, MA: Harvard University, 1966), p. 125, 11. 1353-54. All quotations of this text will be provided parenthetically hereafter.

37. Euripides, Euripidis Hecuba et Iphigenia Latinae factae, trans. Desiderius Erasmus in Desiderius Erasmus, Opera omnia, Ordinis primis, Tomus primus (Amsterdam: North-Holland Publishing Company, 1969), p. 345, 11. 1920-22. Quotations of this text will be provided parenthetically hereafter. 
38. For a discussion of her alterations, see Patricia Demers, "On First Looking into Lumley's Euripides," Renaissance and Reformation / Renaissance et Réforme 23.1 (1999), pp. 25-42.

39. "Ut est misertum! Supplicabit haec mihi / Ad hunc, reor, modum: 'O pater, me occidere / Paras? At istius modi connubia / Veniant tibique et si quis est carus tibi" (How it distresses me! She will entreat me, / I think, in this manner: "O father, to kill me / Do you prepare? But may nuptials of this manner / Come both to you and anyone who is dear to you"): Erasmus, Iphigenia, 11. 596-99.

40. "An hoc tantum sat est, / Sceptris ferundis praeminere ac bellicum / Ducem vocari” (Or is only this enough, / By bearing scepters to excel, and a warlike / Captain to be called): Erasmus, Iphigenia, 1l. 1687-89.

41. "(uti vides) ad nauticas et efferas / Mulier adveni phalanges" (as you see, to these savage naval phalanxes / A woman I have come): Erasmus, Iphigenia, 1l. 1252-53.

42. Jocelyn Catty, Writing Rape, Writing Women in Early Modern England: Unbridled Speech (New York: St. Martin's Press, 1999), pp. 137-38; Demers, p. 37.

43. "At nunc quidem in te, haud aliubi, mea filia, / Sum totus, omni dedicatus pectore" (But now indeed, my daughter, I am all yours, / By no means elsewhere, devoted with all my heart): Erasmus, Iphigenia, 11. 865-66. 